\title{
Teaching Video NeuroImage: Impaired bilateral conjugate eye movements in a 48 -year-old man
}

Mao Liu, MD, Dr med, Jing Zhang, MD, PhD, and Min Zhang, MD, PhD

Neurology ${ }^{\circledR}$ 2020;94:e1966-e1967. doi:10.1212/WNL.0000000000009382

Figure Lesion ventral to the cerebral aqueduct in the pontomesencephalic junction

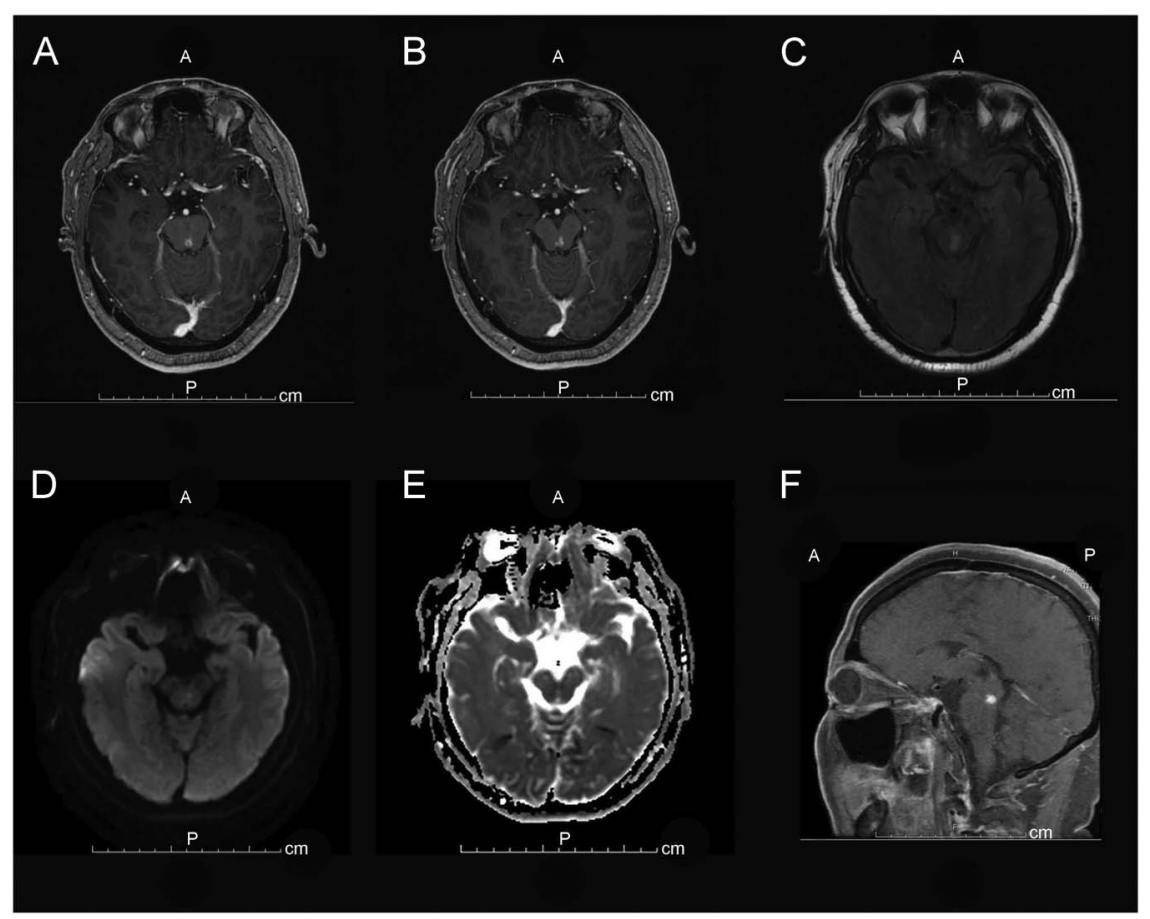

Increased signal on T2 fluid-attenuated inversion recovery (C) and postcontrast enhancement (A, B, and F) is seen. Mildly increased and decreased signals on diffusion-weighted imaging (D) and apparent diffusion coefficient (E), respectively, suggest weak diffusion restriction, supporting a diagnosis of ischemic stroke in the subacute phase.

A 48-year-old man developed lightheadedness and diplopia upon awakening 10 days prior. Since then, his double vision had been continuous and stable. Upon admission, neurologic examination revealed bilateral internuclear ophthalmoplegia, abducting nystagmus, and intact convergence reflex (video). His blood pressure was $155 / 100 \mathrm{~mm} \mathrm{Hg}$ and $\mathrm{HbAlc}$ was $8.7 \%$, suggesting a new diagnosis of diabetes mellitus type 2. CT angiography showed calcified plaques of bilateral cavernous internal carotid arteries. MRI showed a lesion with hyperintensity on T2 fluidattenuated inversion recovery, contrast enhancement, and mild diffusion restriction ventral to the cerebral aqueduct in the pontomesencephalic junction (figure), which is supplied by interpeduncular perforating branches of posterior cerebral arteries. ${ }^{1}$ For this patient with hypertension and diabetes mellitus, the acute onset of symptoms and imaging findings suggest ischemic stroke due to arteriolosclerosis of perforating arteries, which should be differentiated from demyelinating diseases such as multiple sclerosis. Involvement of bilateral medial longitudinal fasciculus rather than oculomotor nucleus is a rare consequence of stroke. ${ }^{2}$

\section{Correspondence}

Dr. M. Zhang

mzhang@tjh.tjmu.edu.cn
MORE ONLINE

๑ Video

\section{$\rightarrow$ Teaching slides}

links.lww.com/WNL/ B78 


\section{Appendix Authors}

\begin{tabular}{lll}
\hline Name & Location & Contribution \\
\hline $\begin{array}{l}\text { Mao Liu, MD, } \\
\text { Dr med }\end{array}$ & $\begin{array}{l}\text { Tongji Medical College, } \\
\text { Huazhong University of } \\
\text { Science and Technology, } \\
\text { Wuhan }\end{array}$ & $\begin{array}{l}\text { Designed the study; } \\
\text { collected, analyzed, and } \\
\text { interpreted the data; } \\
\text { wrote and revised the } \\
\text { manuscript }\end{array}$ \\
\hline $\begin{array}{l}\text { Jing Zhang, } \\
\text { MD, PhD }\end{array}$ & $\begin{array}{l}\text { Tongji Medical College, } \\
\text { Huazhong University of }\end{array}$ & $\begin{array}{l}\text { Analyzed and } \\
\text { interpreted the data, } \\
\text { revised the manuscript }\end{array}$ \\
\hline $\begin{array}{l}\text { Science and Technology, } \\
\text { Wuhan }\end{array}$ & $\begin{array}{l}\text { Designed the study, } \\
\text { MD, PhD }\end{array}$ & $\begin{array}{l}\text { Tongji Medical College, } \\
\text { Huazhong University of } \\
\text { interpreted the data, } \\
\text { revised the manuscript }\end{array}$ \\
& Wuhan and Technology, & \\
\hline
\end{tabular}

\section{Study funding}

No targeted funding reported.

\section{Disclosure}

The authors report no disclosures relevant to the manuscript. Go to Neurology.org/N for full disclosures.

\section{References}

1. Marinkovic S, Milisavljevic M, Kovacevic M. Interpeduncular perforating branches of the posterior cerebral artery: microsurgical anatomy of their extracerebral and intracerebral segments. Surg Neurol 1986;26:349-359.

2. Frohman TC, Galetta S, Fox R, et al. Pearls \& Oy-sters: the medial longitudinal fasciculus in ocular motor physiology. Neurology 2008;70:e57-e67. 


\section{Neurology}

\section{Teaching Video NeuroImage: Impaired bilateral conjugate eye movements in a 48-year-old man \\ Mao Liu, Jing Zhang and Min Zhang \\ Neurology 2020;94;e1966-e1967 Published Online before print April 21, 2020 \\ DOI 10.1212/WNL.0000000000009382}

\section{This information is current as of April 21, 2020}

\section{Updated Information \&} Services

References

Subspecialty Collections

Permissions \& Licensing

Reprints including high resolution figures, can be found at: http://n.neurology.org/content/94/18/e1966.full

This article cites 2 articles, 1 of which you can access for free at: http://n.neurology.org/content/94/18/e1966.full\#ref-list-1

This article, along with others on similar topics, appears in the following collection(s):

All Cerebrovascular disease/Stroke

http://n.neurology.org/cgi/collection/all_cerebrovascular_disease_strok

Diplopia (double vision)

http://n.neurology.org/cgi/collection/diplopia_double_vision MRI

http://n.neurology.org/cgi/collection/mri

Nystagmus

http://n.neurology.org/cgi/collection/nystagmus

Ocular motility

http://n.neurology.org/cgi/collection/ocular_motility

Information about reproducing this article in parts (figures,tables) or in its entirety can be found online at:

http://www.neurology.org/about/about_the_journal\#permissions

Information about ordering reprints can be found online:

http://n.neurology.org/subscribers/advertise

Neurology ${ }^{\circledR}$ is the official journal of the American Academy of Neurology. Published continuously since 1951, it is now a weekly with 48 issues per year. Copyright (O) 2020 American Academy of Neurology. All rights reserved. Print ISSN: 0028-3878. Online ISSN: 1526-632X.

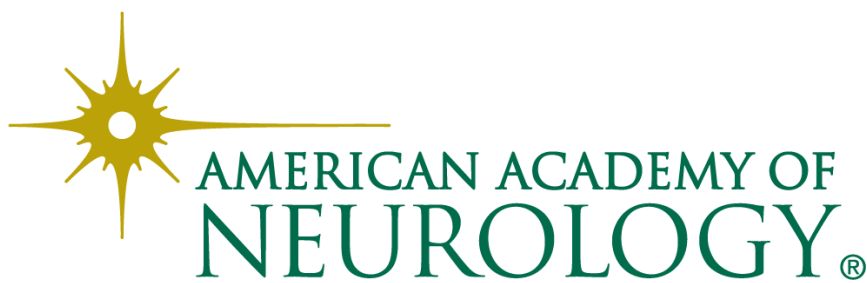

